\title{
Committed Drama and the Dissemination of Dissent
}

Le Théâtre engagé et la diffusion de la contestation

\section{Georges Fournier}

\section{CpenEdition}

Journals

Electronic version

URL: http://journals.openedition.org/rfcb/1513

DOI: $10.4000 / \mathrm{rfcb} .1513$

ISSN: 2429-4373

Publisher

CRECIB - Centre de recherche et d'études en civilisation britannique

Electronic reference

Georges Fournier, "Committed Drama and the Dissemination of Dissent », Revue Française de

Civilisation Britannique [Online], XXII-3 | 2017, Online since 05 July 2017, connection on 19 April 2019.

URL : http://journals.openedition.org/rfcb/1513; DOI : 10.4000/rfcb.1513

This text was automatically generated on 19 April 2019

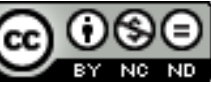

Revue française de civilisation britannique est mis à disposition selon les termes de la licence Creative Commons Attribution - Pas d'Utilisation Commerciale - Pas de Modification 4.0 International. 


\title{
Committed Drama and the Dissemination of Dissent
}

\author{
Le Théâtre engagé et la diffusion de la contestation
}

Georges Fournier

\section{Introduction}

1 While commitment is a term whose meaning can easily be delineated because of its political dimension, the notion of media proves far more difficult to define when envisaged in conjunction with drama, especially when, as in the case of committed drama, the main purpose is to inform rather than merely to entertain. Committed drama is the generic term chosen in this paper to deal with a genre whose functions are: to tackle topical issues, provide unconventional and challenging viewpoints, educate the population and attempt to be experimental on stage and in the management of theatre companies. The Living Newspaper occupies a seminal position in the committed drama of the Anglo-Saxon world; it has its roots in The Federal Theatre Project (1935-39), a programme set up by the US government as part of the New Deal and designed to help fight the disheartening atmosphere of distress brought about by the Great Depression through live performances. ${ }^{1}$ Though very successful, it was soon disbanded following accusations of communist propaganda. ${ }^{2}$ In the UK, it is best known in the form of the Theatre Workshop, Joan Littlewood's company, which was most famous in the 50s and 60s and cannot be envisaged either without references to fellow Europeans who pioneered the genre: Erwin Piscator, Bertolt Brecht and the epic theatre. ${ }^{3}$

Do The Living Newspaper and it successors belong to media as defined by the Longman dictionary, namely: "organizations such as television, radio, and newspapers that provide news and information for the public, or the people who do this work"? Even though drama is not explicitly listed in the definition mentioned above, the connections between epic theatre - The Living Newspaper and the Theatre Workshop - and media are obvious on at least one count: right from the start, epic theatre claimed to be a provider of unconventional approaches to information and consequently insisted on being a vehicle 
for information, though it would also be critical of the media and of realistic aesthetics. The notion of realism is twofold: it refers to mimetic methods that advocate verisimilitude ${ }^{4}$ and to the choice social issues.

3 Criticism stands at the heart of committed drama and the genre creators' original intention was to set up an agency to offer different and committed viewpoints on current events. It corresponded to an avant-garde way of conveying information. Therefore, committed drama, as a media, will be approached through politics, politics meaning, in the present study, both the treatment of topical issues and also a collectivist experience to be extended to all the spheres of human activity.

4 The first part of this essay will focus on an analysis of committed drama as a form of media and then will examine to what extent it inspired other alternative undertakings. Time proved that committed drama, in its different forms, was so effective in the transmission of information that it was quickly taken up by television, the epitome of mass-media. This will be the focus of the last part of this article.

\section{The Living Newspaper and the origins of committed drama in the UK}

5 The adjective "popular" is inextricably connected with the notion of media since both include closeness and availability and with time the word media has gradually become synonymous with mass media. The Living Newspaper was the original appellation for theatrical and dramatic entities presenting current events to a popular and local audience. It borrowed heavily from journalism, both in its title and in its topics, to attract people to an alternative form of information, as explained by Paul Sporn:

They [agit-prop plays] were shaped by techniques designed to engage audiences directly in the purpose of the context in which they appeared. Because of their topicality and style of presentation, they contained the germ of the more complex drama form, The Living Newspaper. ${ }^{5}$

6 Among its main features was the fact that The Living Newspaper was information through entertainment. It was the dramatisation of controversial issues. Busmen, for example, a play about the trial of the leaders of the Busmen's strikes before the union executives in the 1930s, juxtaposed cinematic cuttings and inserted verses as well as comic sequences in a series of "gestic episodes" ${ }^{\circ}$ on what was then a burning social issue. ${ }^{7}$

7 Originally, the popularity of The Living Newspaper was accounted for by the fact that it was part of a project set up by Roosevelt to give work to people in the entertainment industry following the crisis of $1929 .{ }^{8}$ Repeated on several occasions, this initiative was definitively abandoned during the McCarthy era because the artists of the time were seen as having links with European left-wing movements. ${ }^{9}$

Focusing on tensions to generate controversy and using unconventional forms of representation, The Living Newspaper was a highly creative form of drama with plays which, each in its own way, pinpointed the causes and possible consequences of the topic chosen. The Living Newspaper productions represented examples of "the documentary impulse", ${ }^{10}$ with their emphasis on facts, which had a strong impact in the United Kingdom, a country where experiments in the representation of reality have always been received with enthusiasm, as borne out by the documentary movement. ${ }^{11}$ Each identified a significant social problem, explored the issues surrounding it, and suggested possible 
solutions. Power, for instance, focused on electrification and the ownership of public utilities while One-Third of a Nation, another play, dealt with the problem of housing and the appalling living conditions of part of the population. ${ }^{12}$

According to Brooks Atkinson, a New York Times drama critic, playwrights were "to shake the living daylights out of a thousand books, reports, newspaper and magazine articles" to create documentaries based on current news stories. The project involved a team similar to that of a large city newspaper, with editors, reporters, and copyreaders. News gathering and research were paramount. The factual material collected by reporters and researchers was given to dramatists, directors, stage technicians, and actors who would create fiction for presentation to an audience. Dialogue in each of the plays often quoted newspapers and magazine articles to lend authenticity to the script.

10 The Living Newspapers companies were composed of politically motivated individuals and so represented collective efforts. The notion of collectivity was essential for the companies which based their functioning on decisions taken democratically, the company being itself founded on principles the actors and participants advocated for the society at large and from which Joan Littlewood borrowed heavily. ${ }^{13}$

\section{Joan Littlewood and the Theatre Workshop}

11 As suggested above, originally, British committed drama drew its inspiration from the practice at the time in the United States. In a 1994 broadcast which BBC1 dedicated to Joan Littlewood, ${ }^{14}$ the well-known British actress and director, she explained how she experimented with The Living Newspaper by adapting it to the British audience. After the fashion of what had been done by theatre companies in the United States, but also in Russia and in Germany, Joan Littlewood's experiment consisted in extracting information and issues from the press to which her drama company, by then termed Theatre Workshop, ${ }^{15}$ would bring a critical treatment. In her interview, Joan Littlewood compares this type of performance to some form of artistic "happening" even though she lays emphasis on her work as alternative journalism. She speaks about her practice on the treatment of information as a political assignment with a view to raising the spectator's awareness regarding the point of view that she wanted to put forward: rather than providing a conventional show, the realistic nature of which would trivialise issues the way Hollywood film-making had trivialized fiction on both the small and big screens, she would borrow heavily from the epic-theatre which demanded that the audience think in a challenging way about politics but also about drama, drama being not only entertainment but also a channel for the dissemination of information.

12 As a consequence, their audacity would not be restricted only to the choice of topics. Its scope would be more far-reaching and would involve the company and all its organisation: dedication to committed drama meant recruiting performers who had not received conventional training, sometimes no training at all, and who were not "actors" in a narrow sense. As for the management of the company, a process of bottom-up decision making would, theoretically, be promoted. This innovative approach to dramamaking highlighted the highly political dimension of Joan Littlewood's work which sought to break away from the segmentation of competences, whether in acting or in management, as explained by Derek Paget in True Stories?: Documentary Drama on Radio, Screen, and Stage: 
Lovely War was constructed upon a collectivist principle as unlike dominant modes of composition as can be imagined. The controlling notion for Theatre Workshop was that all aspects of production, including writing, were essentially collective, a concept born in pre-war days. In order to measure that even writing remained part of a process in which, for the overall health of the enterprise, the contribution of the individual should not be valorized, extreme measures were sometimes taken. At Stratford East, it was writers' as well as actors' egos which were sacrificed to the common cause. ${ }^{16}$ productions, whether on TV or in cinematic films, that is to say highly conventional and normative representations that promoted capitalism and its pervasive and uncritical view of consumerism. To oppose realism, Joan Littlewood encouraged the use of improvisation. Improvisation was the core of the acting process within the Theatre Workshop company, replacing conventional methods, like rehearsal for instance, and spilling over into performance with the audience occasionally invited to participate, as aptly explained by Robert Leach about the situation of drama in the USSR just after World War I:

The style of acting resembled the old troupes of strolling players and was often rooted in improvisation based on character types. Because the news changed day by day the actors often had only time to agree on the form of the sketch before going on stage, and performing in the open air they frequently had to cope with interjections and heckling from the audience. On one occasion an agitator interrupted the performance to announce the defeat of Denikin. The audience burst out cheering and the actors improvised a scene of Denikin dancing, then being chased off by Red Army soldiers. ${ }^{17}$ 
which "introduced a new sense of social solidarity and social idealism which led to a consensus on welfare state reforms". ${ }^{21}$

Closeness and topicality were also at the centre of Joan Littlewood's Theatre Workshop whose itinerant company toured the UK from 1945 to 1953, the year they decided to settle in Stratford. Bringing the information as close as possible to the population was Joan Littlewood's ambition after World War II when she decided to transform her company into an itinerant structure, something which would increase flexibility and proximity to the population. During more than eight years, performances were improvised across the whole country to promote an alternative form of information and bring it to where people lived and worked.

The willingness to combine aesthetic and didactic elements constitutes one of the distinctive features of this dramatic genre which docudrama also possesses, in its cinematic form after World War II and in television in the 1960s.

\section{Aesthetic criteria}

21 The links between drama and cinema are close and the Theatre Workshop's founding manifesto of 1945 proclaimed the intention "to create a flexible theatre art, as swift moving as the cinema". ${ }^{22}$ Yet, it would be mistaken to equate post-World War II cinema with a unique filmic performance; in the 40's, cinema meant the succession of different types of screenings, fictional, journalistic, documentary and even propagandistic, that would unfold one after another, all the genres being often of quasi-equal importance in the eyes of the viewers. As for the distinction between entertainment and information, it was considerably blurred in the process.

One of the characteristics of epic theatre, which was taken up by the docudramas of the 60 s, is hybridization. The genre promoted the combination of factual and poetic elements, sometimes even openly lyrical ones. In the Theatre Workshop, envisaged as an instrument of information, aesthetics is inextricably connected with contents and the cross-genre nature of Joan Littlewood's work aptly fits into the notion of political drama as media. The will to prompt the audience to tackle issues in a different way is found in the numerous instances of direct address; the metafictional distance or self-reflexivity ${ }^{23}$ that would ensue was meant to oppose the extensive use, on both small and big screens, of realistic aesthetics that is to say "smooth, seamless professionalism ${ }^{24}$ which was perceived as reactionary and which consequently went against the idea of educating the population. This strategy was highly political and the audience, all through the play, was led to adopt a critical perspective on things staged, which were then to be questioned and challenged. Very often, the audience was effectively being offered an exercise in Brechtian "complex seeing", 25 in a light and playful way and characters or narrators continually encouraged the questioning of "truths". Audiences would comment spontaneoulsy and this would heighten the feeling of authenticity; actors would answer the comments, introducing some form of dialogue that, in the process, helped dispel the feeling that the audience was being fed propaganda.

The use of open stages, a defining criterion of this type of drama, was conducive to direct contact with the audience. Right from its inception, the Theatre Workshop broke away from the formalities of conventional staging, embracing the audience on three sides. While in ordinary proscenium theatre stages, the audience was face-to-face with the 
actors, in committed drama, the open stage meant that actors were surrounded by the audience, a device that increased proximity, spontaneity and interaction. The actors would then become active intermediaries between the audience and the issue itself. This setting was in keeping with notions of fluidity and flexibility since the actors would restlessly move around the stage so that people among the audience, wherever they were seated or standing, would see each and every one of their gestures and facial expressions. It echoed the approach of the Theatre Workshop as drama best suited to adapt to events that rocked the world, be they economic, political, social or even environmental. These companies were determined to "create a form which was infinitely flexible", able to "move backwards and forwards in time and space as ... with.... film". ${ }^{26}$ As an example, Uranium 235, a play whose topic had been suggested by the bombings of Hiroshima and Nagasaki constantly alternated styles, partly because it was hastily written but also to keep the contact with the audience open. Spontaneity and imperfection would lay spaces open for the audience to participate. In May 1945 Joan Littlewood's Theatre Workshop toured with Uranium 235. Uranium 235 reviewed the history of science up to Hiroshima through a complex mixture of styles which spanned almost two decades of nuclear experiments. It went down a storm with the working-class audience. The audience took it on their own terms, they cheered as if it were a variety show, which proved how successful Joan Littlewood's company was. All these efforts to establish direct contact with the audience were politically motivated and designed to introduce some break from realism.

Joan Littlewood's Theatre Workshop and the companies that were doing committed drama were critical of conventional media which used realism even in the treatment of information, something they considered to be deception. By producing a powerful effect of reality, realism leads to projection and identification which are obstacles to a critical approach of the issues under examination; it induces adherence, something conventional media have been criticized for by analysts of the media ever since the Frankfurt School. ${ }^{27}$ For committed drama advocates, political commitment and aesthetic experiments had to work together in a tight tandem.

As explained above, the Theatre Workshop encouraged a bottom-up treatment of social and political issues that went against the ancestral top-down and highly hierarchical organization of society. Criticizing the conventional medias that acted as channels for a paternalistic organization of society with those in power dictating to the rest of the population what and how to think, the Theatre Workshop offered opportunities for alternative outlooks on issues and offered those usually excluded the opportunity to have a say and express divergent opinions. All this greatly broadened the definition of committed drama: beyond being a provider of information, it became a recipient of original reactions and unfulfilled expectations. It anticipated the naturalistic British television films of the 50s and 60s by Ken Loach and Peter Watkins, filmmakers who, as embodiments of the working class recently allowed to attend university, intended to use TV as a channel for the promotion of political issues and as an alternative source of entertainment and information that would, in terms of quality, compete with arts, drama and literature. 


\section{Media is medley} Originally staged by Joan Littlewood and the Theatre Workshop, it was inspired by The Donkeys, a play by Alan Clark, to which scenes borrowed from The Good Soldier Svejk by Jaroslav Hasek, a Czech humorist, were added. ${ }^{30}$ Its subject was World War I, which the musical handled with subtlety. The relevance of the subject with regard to the 1960s was explained by the persistence of the conflicts worldwide, among which the Vietnam War, the Cold War and the escalation of the nuclear armament on either side of the Iron Curtain. More than a pacifist allegory, Oh What has Lovely War aimed to voice the playwright's political stance on the then current issues, even though it was in a tangential way.

The play was highly criticised at the time and the criticisms were all the more harsh as those who worked with Joan Littlewood were accused of having communist sympathies. Her work was criticized mainly because it was "seen by some people as 'anti-British propaganda", ${ }^{31}$ though few saw the connection with what was going on in the world at 
the time: "The major achievement of Oh What a Lovely War was to question the long held national myth that World War I had been won. The production asked by whom was it won, and on whose behalf?" 32 "A play about the past - safely remote". ${ }^{33}$

31 From a technical point of view, the sophistication of Oh What a Lovely War fitted perfectly with a society that was embracing technology as never before and it combined many elements from the media available at the time. Its cutting edge derived from a combination of selected documentary material and inventive stage assemblages. The first audiences of Oh What a Lovely War watched a production cut like a movie with many different sketches, structured as light entertainment. The performers offered "songs ... battles and some jokes", ${ }^{34}$ there were also facts, statistics and documentary photographs presented as part of a multi-media environment, elements more in keeping with journalism than drama. Above the stage, a newspanel displayed moving messages and words moved slowly and steadily enabling spectators to read statistics, location, time and sometimes comments.

A news panel and a translucent projection screen reinforced the information dramatised by the performers in a variety of theatrical styles, including dancedrama, agit-prop, slapstick comedy, direct-address monologues, songs and dances. The news panel was a 'ticker-tape' machine, like those used on buildings in big cities such as London and New York to relay news. ${ }^{35}$

Technology bridged the gap between documentary and drama permitting the circulation of information as never before. As far as rhythm was concerned, the pace provided by the special effects was as important as that provided by the actors.

\section{Stuff Happens and Embedded: the revival of the verbatim tradition}

American Administration and denouncing the support brought to it by the Blair government. The same year, in the Tricycle Theatre ${ }^{36}$ - Guantanamo was performed: this play highlighted the plight of the prisoners in Guantanamo and condemned the Bush Administration's policies regarding the fight against terrorism. Following in the footsteps of Guantanamo, Stuff Happens ${ }^{37}$ and Embedded ${ }^{38}$ - two plays that denounced British support of United States foreign policy in the Middle-East - adopted the same critical approach. The popularity of these plays was partly due to the decision to tour campuses in the UK and in the USA so as to be as close as possible to the population; it testified to the capacity of the genre to be envisaged as a valuable channel for the provision of divergent viewpoints from those afforded by the mainstream medias.

As heirs to the tradition introduced by The Living Newspaper, these plays provided alternative comments from those delivered daily by the media and echoed the massive waves of protest that rallied demonstrators in the UK in 2003. ${ }^{39}$ Belonging to the genre of verbatim drama, these plays used official statements and testimonies of high-profile 
figures delivered to the media to construct the narrative, the purpose of the genre being to highlight the renegations, lies and contradictions of the policy-makers by piecing together some of their statements later contradicted by their acts or their failure to act. Thanks to hindsight, the verbatim genre affords playwrights collections of declarations made to the press that can be analysed in the light of what really happened so as to shed light on the true nature of the motivations, features that are summed up in an article from The Guardian about Stuff Happens:

[...] a very good compelling play: one that may not contain a vast amount of information but that traces the origins of the Iraq war, puts it in perspective and at the same time astutely analyses the American body politic..$^{40}$

Regarding the treatment of British politics, one of the highlights of the verbatim drama was Called to Account which The Tricycle Theatre advertised as "The Indictment of Anthony Charles Lynton Blair for the Crime of Aggression against Iraq - a Hearing". ${ }^{41}$ The last word of the quotation points unambiguously to the play as a verbatim account of the statements made by the then Prime Minister, the dates and circumstances in which they were uttered serving as elements that further helped substantiate the contentions made by the playwright. Like any other highly political play of this genre, Called to Account echoed the general outcry among the population against the British foreign policy in the Middle-East and served to maintain the feeling of discontent aroused by the Blair government's decision to support the US intervention. It largely tapped into the ethos of doing politics differently as initiated by Joan Littlewood's company, a bottom-up approach that was felt to be more attentive to the opinions of a population that was to be thought of as being educated and critical. Though ludicrous at first sight, the decision to take a Western leader to court for crimes was justified on several counts, the first one being the fact that there were precedents ever since World War II and secondly that it was felt to be the only way for the population to absolve itself of the shame they felt through having elected someone some still see as a criminal. ${ }^{42}$

This type of theatre shares with docudrama, in cinema and on television, a will to generate debates by questioning the official policies. Its relevance lies in the all-out and frontal nature of the attack. As it is often the case with docudrama, the purpose is to encourage the public to adopt a critical viewpoint, generally on domestic issues. It is what Peter Kosminsky did, on identical topics, in The Government Inspector (2005), about the state lies to win over the parliamentary vote to join the US forces in Iraq and in The Project (2002), about cynicism in politics.

\section{TV as the latest recipient of committed drama}

The link between drama and television is not fully acknowledged, so as to avoid generating confusion between arts on the one hand and the media industry on the other hand. If the closeness between television and cinema is undeniable, because of the use of identical techniques, the link between drama and television, especially in its early stages, was also very strong.

The theatrical experiments carried out before World War II, and which were resumed in the late 1940s, considerably influenced the television docudrama directors of the 1960s. Following the tradition initiated by the experimental Theatre Workshop, the early filmmakers of the 50s and 60s, like Peter Watkins and Ken Loach, approached television the way Erwin Piscator and his followers approached committed drama, namely as a 
political instrument that would contribute to the birth of the homo politicus. Cornerstone programmes followed in Joan Littlewood's footsteps and Peter Watkins, for one, considered films as experiments in politics, from the very beginning of his career. $L a$ Commune, without doubt one of the most politically avant-gardiste productions, stands out as an exemplar in participative drama: though the film was finished in 2000, the experiment still lives on through the comments posted on the film's website by the participants and through the events that the film still gives rise to. ${ }^{43}$

Peter Watkins was most eager to demonstrate the political implication of aesthetic choices. Aesthetics stood at the heart of the early commitments for which he fought as a young director at the BBC, with Culloden (1964) and The War Game (1966), and to which he has remained faithful to this day. From his point of view, politics has much to do with the creative process. For Peter Watkins, separating the two is a dangerous thing and refusing to acknowledge the political dimension of aesthetics may result in the adoption of a transparent narrative mode, as imposed by the audiovisual media. The issue was all the more topical in the 1960s as drama was still praised as an art to be admired and imitated and, as such, it still accounted for a major part of the programmes, hence the titles of the most famous ones: Play of the Week (ITV, on 1955-1968), Play for Today (BBC1, 1970-1984), The Wednesday Play (BBC1 1964-1970).

On television, the influence of the experimental drama was obvious with the work of scriptwriters who opted for the treatment of political issues then widely debated in society, like abortion (Up the Junction, 1965), the lack of healthy accommodation (Cathy Come Home, 1966), job insecurity (The Lump, 1967), labour disputes (The Big Flame, 1969), old-age difficulties (Edna the Inebriate Woman, 1971) and social determinism (Poor Cow, 1967). The working-class origin of some of these scriptwriters, like Jim Allen and David Mercer for example, gave them the inclination to report on what they had been through; their experience, which constituted first-hand material, lent the fiction films in question their documentary value.

Even though the intention was originally political, the observational stance ${ }^{44}$ was not an obligation and Up the Junction developed a documentary strategy that showed defiance towards artifice and self-reflexivity. The experimental television films of the mid-60s were characterized, in the choice of topics, by realism in so far as their main concerns were social issues and the ordinary lives of workers. "What is being discussed here is the moment of 'Anger' and 'Working Class Realism' on television", ${ }^{45}$ and it was so largely thanks to the BBC's Wednesday Play which was the most prominent programme to host this kind of drama on TV.

In 1964 the BBC broadcast Diary of a Young Man which was about the adventures of two young working-class men from the North during their first few months in London, and their attempts to seek their fortune. They set about looking for work and somewhere to live. Directed by Ken Loach and written by Kennedy Martin and John McGrath, the sixpart series was meant to provide a practical example of non-realistic series which included "narration, a dense soundtrack, still images, filmed montage" 46 and voice-over. All of this was designed to involve the viewer in a drama that was intellectually demanding and that more "pedantic" ${ }^{47}$ genres had failed to provide. The reference to voice-over is particularly informative, since it highlights one of the techniques that marked both Up The Junction, and Cathy Come Home as being distinctively documentary in their intention compared to other contemporary dramas and films. Voice-over was used primarily as a technique borrowed from documentary, and can be related to other 
strategies that were designed to highlight the filmmaker's willingness to provide a document that would have a testimonial value: the use of $16 \mathrm{~mm}$ film, which is associated with news and current affairs; the casting of non-professional actors, and the use of seemingly overheard, rather than scripted, dialogues, in short, what John Caughie has referred to as the "documentary look". ${ }^{48}$ This strategy served to authenticate what was being represented. The need for the filmmakers to give something that appeared authentic derived from their will to use fiction, which was not considered as the adequate medium, to get personal viewpoints about current issues across.

In Who Bombed Birmingham? (1990), Mike Beckham shot scenes which could be clearly identified as profilmic events, that is to say as if they had been captured when they were taking place and the camera was on. Journalists and operators from the World in Action investigative programme are seen preparing the interview of one of the key witnesses of the Birmingham bombings. In the frame, props and lighting equipment are visible, reminiscent of the journalistic genres but which are usually totally proscribed in fiction. The stand taken by the filmmaker is to show the innocence of the four indictees: they were victims of the police's need to offer guilty people to officials and to the outraged population. Evidence was forged and those arrested were quickly sentenced to lifeimprisonment. Who Bombed Birmingham? followed an investigation conducted in 1985 by the journalists of World in Action, whose programme was however broadcast on March 18, 1991, i.e. four days after the rendering of the verdict and more than a year after the broadcasting of Mike Beckham's fiction film. Uncannily, the World in Action documentary borrowed images from the fiction film, which was quite unheard of in the history of fiction on television. As in the case of Cathy Come Home, it would be bold to claim that a film, more than popular mobilization, and even politicians, can by itself right a wrong. However, in the long-lasting mobilization for the retrial of the Birmingham Six, Mike Beckham's film played the role of catalyst before any other form of information, including newspapers, reports or documentaries, which testifies to the capacity of committed fiction to publicise a just cause.

Fiction proved that it could be quicker and do better than journalism, something the playwrights who worked for the epic theatre were aware of because of drama and fiction's great capacity to attract the population's attention to burning issues.

Yet, Who Bombed Birmingham? represented the last attempt by a film director to educate viewers to a critical approach of the multimedia material. The intrusion of extradiegetic elements in the filmic frame, designed to puzzle viewers and prompt them to wonder about the issues and the way they were represented on TV, was the televisual equivalent of the dramatic scenery and of the apron stage which Joan Littlewood used to provoke critical appraisal of current issues from the audience.

47 The long-held tradition of committed programmes on television has lately been taken up by directors like Peter Kosminsky and Paul Greengrass whose purpose has been to tackle recent burning issues in Great-Britain like multiculturalism, the British foreign policy and violence. The main difference between these modern filmmakers's films and the early docudramas of the 1960s, by Ken Loach and Peter Watkins, is that they used the realistic aesthetics which television has since imposed in all its programmes, including news. Their bodies of work have largely reneged on one of the major claims of the early TV filmmakers, who drew much of their inspiration from the epic theatre, namely the education of the audience, though they have managed to maintain the other two original assignments: to entertain and to inform. 


\section{Conclusion}

$$
\text { progr }
$$
needs to be questioned to try and adjust television to educational rather than purely
entertaining assignments, something drama did when, with the epic theatre, it shifted its needs to be questioned to try and adjust television to educational rather than purely
entertaining assignments, something drama did when, with the epic theatre, it shifted its focus from entertainment and education to information.

Maître de conférences à l'Université Jean Moulin Lyon 3, Georges Fournier enseigne en langue et civilisation britanniques. Les médias britanniques, et en particulier la télévision, constituent son principal axe de recherche. Il a publié de nombreux articles dans des revues françaises et étrangères et travaille actuellement sur les représentations des enjeux politiques.

\section{BIBLIOGRAPHY}

Beattie, Keith, Documentary Screens: Nonfiction Film and Television (Basingstoke, Palgrave Macmillan, 2004).

Bignell, Jonathan and Lacey, Stephen Popular Television Drama: Critical Perspectives (Manchester: Manchester University Press, 2005).

Casson, John W., Living Newspaper: Theatre and Therapy ((TDR (1988-), Vol. 44, n², Summer 2000).

Fiske, John and Hartley, John, Reading Television (London, Routledge, 2003).

Goorney, Howard and MacColl, Ewan, Agit-prop to Theatre Workshop: Political Play Scripts, 1930-50

(Manchester, Manchester University Press, 1986).

Holdsworth, Nadine, Joan Littlewood's Theatre (Cambridge, Cambridge University Press, 2011).

Jullier, Laurent, L'Analyse de séquences (Paris, Armand Colin, 2000).

Kahana, Jonathan, The Documentary Film Reader: History, Theory, Criticism (Oxford, Oxford University Press, 2016). 
Kuritz, Paul, The Making of Theatre History (Englewood Cliffs, NJ: Prentice Hall, 1988).

Littlewood, Joan, Oh What A Lovely War (London, Bloomsbury Publishing, 2014).

Leach, Robert, Revolutionary Theatre (Oxon, Routledge, 2005).

Monaco, James, How to Read a Film: The Art, Technology, Language, History, and Theory of Film and Media (Oxford, Oxford University Press, 1981).

Nealon, Jeffrey T. and Irr, Caren Rethinking the Frankfurt School: Alternative Legacies of Cultural Critique (New York, State University of New York Press, 2012).

Nichols, Bill, Representing Reality: Issues and Concepts in Documentary (Bloomington and Indianapolis, Indiana University Press, 1991).

Nicholson, Steve, Modern British Playwriting: the 60s: Voices, Documents, New Interpretations (London, Bloomsbury, 2012).

Paget, Derek True Stories? Documentary Drama on Radio, Screen, and Stage (Manchester, Manchester University Press, 1990).

Paget, Derek, Verbatim Drama: Oral History and Documentary Technique, New Drama Review (1987).

Rolston, Bill, Media and Northern Ireland (Basingstoke, MacMillan, 1991).

Smith, Harold, L., Britain in the Second World War: A Social History, Volume 1 (Manchester, Manchester University Press, 1996).

Sporn, Paul, Against Itself: The Federal Theater and Writers' Projects in the Midwest (Detroit, Wayne State University Press, 1995).

Stoller, Terry, Tales of the Tricycle Theatre (London, Bloomsbury Methuen Drama, 2013).

Thomson, Peter and Kershaw, Baz, The Cambridge History of British, Theatre, Volume 3

(Cambridge, Cambridge University Press, 2004).

Wilmeth, Don B., The Cambridge Guide to American Theatre (Cambridge, Cambridge University Press, 1996).

Witham, Barry, The Federal Theatre Project: A Case Study (Cambridge, Cambridge University Press, 2003).

\section{NOTES}

1. Witham, Barry, The Federal Theatre Project: A Case Study (Cambridge, Cambridge University Press, 2003).

2. Ibid.

3. Kuritz, Paul, The Making of Theatre History (Englewood Cliffs, NJ: Prentice Hall, 1988).

4. Fiske, John and Hartley, John, Reading Television (London, Routledge, 2003).

5. Sporn, Paul, Against Itself: The Federal Theater and Writers' Projects in the Midwest (Detroit, Wayne State University Press, 1995).

6. Thomson, Peter and Kershaw, Baz, The Cambridge History of British Theatre, Volume 3 (Cambridge, Cambridge University Press, 2004).

7. Casson, John W., Living Newspaper: Theatre and Therapy ((TDR (1988-), Vol. 44, n²2, Summer 2000).

8. Witham, Barry, The Federal Theatre Project: A Case Study (Cambridge, Cambridge University Press, 2003). 
9. Wilmeth, Don B. and Miller, The Cambridge Guide to American Theatre (Cambridge, Cambridge University Press, 1996).

10. Paget, Derek True Stories? : Documentary Drama on Radio, Screen, and Stage (Manchester, Manchester University Press, 1990).

11. Kahana, Jonathan, The Documentary Film Reader: History, Theory, Criticism (Oxford, Oxford University Press, 2016).

12. The Federal Theatre Project, <http://ethw.org/The Federal Theatre Project>, consulted 16 January 2016.

13. Art which foreground concepts such as democratic or collaborative practices. Holdsworth, Nadine, Joan Littlewood's Theatre (Cambridge, Cambridge University Press, 2011).

14. Now and Then: Joan Littlewood, BBC 1968, <http://www.screenonline.org.uk/tv/id/1418889/ index.html>, consulted 16 January 2016.

15. Goorney, Howard, MacColl, Ewan, Agit-prop to Theatre Workshop: Political Playscripts, 1930-50 (Manchester, Manchester University Press, 1986).

16. Paget, Derek True Stories? : Documentary Drama on Radio, Screen, and Stage. Ibid.

17. Leach, Robert, Revolutionary Theatre (Oxon, Routledge, 2005).

18. Goorney, Howard, MacColl, Ewan, Agit-prop to Theatre Workshop: Political Playscripts, 1930-50. Ibid

19. Stories were performed with jokes, music, and songs.

20. Thomson, Peter and Kershaw, Baz, The Cambridge History of British Theatre, Volume 3 (Cambridge, Cambridge University Press, 2004).

21. Smith, Harold, L., Britain in the Second World War: A Social History, Volume 1 (Manchester, Manchester University Press, 1996).

22. Goorney, Howard, MacColl, Ewan, Agit-prop to Theatre Workshop: Political Playscripts, 1930-50 (Manchester, Manchester University Press, 1986).

23. Jullier, Laurent, L'Analyse de séquences (Paris, Armand Colin, 2000).

24. Monaco, James, How to Read a Film: The Art, Technology, Language, History, and Theory of Film and Media (Oxford, Oxford University Press, 1981).

25. Paget, Derek, True Stories? : Documentary Drama on Radio, Screen, and Stage. Ibid.

26. Goorney, Howard, MacColl, Ewan, Agit-prop to Theatre Workshop: Political Playscripts, 1930-50. Ibid.

27. Nealon, Jeffrey T. and Irr, Caren, Rethinking the Frankfurt School: Alternative Legacies of Cultural Critique (New York, State University of New York Press, 2012).

28. Derek, Paget and the notion of Verbatim Drama in: Verbatim Drama: Oral History and Documentary Technique, New Drama Review (March, 12, 1987), pp.317-36.

29. Paget, Derek, True Stories? Documentary Drama on Radio, Screen, and Stage. Ibid.

30. Bowie-Sell, Daisy, Oh What A Lovely War Returns to its First Home (The Telegraph, January 10, 2013).

31. Nicholson, Steve, Modern British Playwriting: the 60s: Voices, Documents, New Interpretations (London, Bloomsbury, 2012).

32. Thomson, Peter and Kershaw, Baz, The Cambridge History of British Theatre, Volume 3 (Cambridge, Cambridge University Press, 2004).

33. Ibid.

34. Littlewood, Joan, Oh What A Lovely War (London, Bloomsbury Publishing, 2014).

35. Ibid.

36. “Alastair Macaulay in the Financial Times began his review with, 'The Tricycle Theatre is the most valuable home of political theatre in Britain today'. Charles Spencer led with, 'There is no theatre in Britain that has told us more in recent years about the way we live now than the Tricycle in Kilburn"'. Stoller, Terry, Tales of the Tricycle Theatre (London, Bloomsbury Methuen Drama, 2013). 
37. The involvement of the UK in Iraq.

38. How journalists got tricked into believing what politicians and the military wanted them to believe by accepting to be embedded.

39. Syalm, Rajeev and Alderson, One Million March against War, The Telegraph (16 February 2003).

40. Billington, Michael, Not Agitprop, just another Take on History, The Guardian (11 September, 2004).

41. Norton-Taylor, Richard, Called to Account, Official Booklet, 2006.

42. Watt, Nicholas, Blair guilty of 'criminal irresponsibility' over Iraq war, says Livingstone, The Guardian (1 December 2015).

43. L'Association Le Rebond pour la Commune, <http://www.critikat.com/actualite-cine/entretien/ l-association-rebond-pour-la-commune.html> consulted 16 January, 2016.

44. Nichols, Bill, Representing Reality: Issues and Concepts in Documentary (Bloomington and Indianapolis, Indiana University Press, 1991).

45. Bignell, Jonathan and Lacey, Stephen Popular Television Drama: Critical Perspectives (Manchester, Manchester University Press, 2005).

46. Ibid.

47. Ibid.

48. Beattie, Keith, Documentary Screens: Nonfiction Film and Television (Basingstoke, Palgrave Macmillan, 2004).

\section{ABSTRACTS}

During a BBC programme devoted to her career, Joan Littlewood described her experiment in committed drama with her company, the Theatre Workshop. Very popular in the 20s and 30s in the United-States, but also in Russia and in Germany, the formula consisted in extracting information from the press, to which the company would bring a fictional treatment that would put a highly political and critical outlook on the issue at stake. Joan Littlewood compared this type of performance to the journalistic version of a "happening". She would see the staging of information as an invitation to resist the trivialization of topical issues due to journalism and its highly repetitive treatment of news and current events. Though the original themes were primarily social, the scope of investigation of committed drama widened very quickly to cover political issues.

More recently, the war in Iraq brought about the rebirth of the epic theatre genre, on both sided of the Atlantic, with performances that challenged governmental policies. Verbatim plays such as Guantanamo (2004) and Called to Account (2007) were staged in both institutional and less conventional venues, from theatres to campuses, as part of a larger project to set up itinerant performances designed to provide dissenting perspectives on international issues. The purpose of this paper will be to try and examine committed drama from aesthetic and political angles and see how far, at critical periods in the British history, it tried to familiarize audiences with divergent viewpoints on topical issues.

$\mathrm{Au}$ cours d'une émission que la BBC lui a consacrée, Joan Littlewood revient sur sa carrière et décrit son expérience du théâtre engagé avec sa compagnie, Theatre Workshop. Très populaire dans les années 20 et 30 aux États-Unis, mais aussi en Russie et en Allemagne, la formule du théâtre engagé consistait à extraire des informations de la presse, auxquelles la troupe de théâtre 
apporterait un traitement fictionnel afin de mettre en évidence une perspective à la fois critique et politique. Joan Littlewood compare ce type de représentation à la version journalistique d'un «happening». Selon elle, la mise en scène de l'information représente une invitation à résister à la banalisation des questions d'actualité. Bien qu'à l'origine les thèmes fussent surtout d'ordre social, le champ d'investigation s'est très rapidement élargi pour couvrir les questions politiques. Plus récemment, la guerre en Irak a contribué à la renaissance du théâtre engagé, de part et d'autre de l'Atlantique, avec des spectacles qui avaient pour mission de mettre en cause les politiques gouvernementales. Des pièces inspirées du théâtre verbatim, telles que Guantanamo (2004) et Called to Account (2007) ont été mises en scène dans des lieux institutionnels et d'autres moins conventionnels, comme des campus, dans le cadre de projets plus vastes destinés à redonner vie aux spectacles itinérants conçus pour contrer les médias traditionnels et offrir, à la population, sur son lieu de vie, des perspectives divergentes sur les questions internationales. Le but de cet article est d'essayer d'analyser le théâtre engagé en tant que média en fonction de données esthétiques et politiques afin de voir dans quelle mesure, à des périodes critiques de l'histoire britannique, il a eu pour ambition de fournir un traitement subversif de l'information.

\section{INDEX}

Mots-clés: théâtre engagé, Joan Littlewood, verbatim

Keywords: agitprop, theatre, commitment, Joan Littlewood, verbatim

\section{AUTHOR}

\section{GEORGES FOURNIER}

IETT, Université Jean Moulin, Lyon 3 